\title{
Comparison of Ilizarov and rail fixator in non union of long bones
}

\author{
Kanwarjit S.Sandhu ${ }^{1}$, Girish Sahni ${ }^{2, *}$, Bhupinder S. Brar ${ }^{3}$, Karamdeep S. Kahal ${ }^{4}$, Gunvinder Singh ${ }^{5}$ \\ ${ }^{1,2}$ Associate Professor, ${ }^{3}$ Professor, ${ }^{4}$ Senior Resident, ${ }^{5}$ Junior Resident, Dept. of Orthopaedic, Government Medical College, \\ Patiala, Punjab, India
}

*Corresponding Author:

Email: sawhneygirish@ gmail.com

\begin{abstract}
Introduction: Non-union of long bones is a challenging scenario to deal with as management of such fractures is difficult. Tibia is common site of non union. ${ }^{1}$ Various modes of treatment are available such as ultrasound, electrical stimulation, bone grafting and bone transport by illizarov and rail fixator. We have compared the role of Ilizarov and Rail fixator devices in our study of 15 patients each under both groups. Only Rail fixator had some more patient tolerance as compared to Ilizarov due to problems such as heavy apparatus.

Materials and Methods: 15 patients of non union long bones in each group from 21 to 60 years with mean age of 37.6 year in group A and 40.5 years in group B. $90 \%$ of the patients were male. Most of the patients had non union of tibia and further the middle one third was more commoly involved in either group. Nine out of 15 patients in both the groups had infected type of non-union. Average shortening was $2.9 \mathrm{~cm}$ in group A and $2.86 \mathrm{~cm}$ in group B. Maximum number of patients had undergone about two previous surgeries. 12 patients underwent acute docking or compression in group A compared to 13 in group B. Three and two patients underwent compression - distraction for treatment of non union in group A \& B respectively. Patients were followed up at 6,12 and 24 week intervals.

Result: In our study union was seen in 13 cases in group A and 14 cases in group B. The duration for union was average 8.8 months and 8.1 months in respective groups. Normal range of motion in nearby joint was achieved in $80 \%$ cases. We had excellent to good limb function in $80 \%$ of the cases in Group A and $86 \%$ of cases as per ASAMI scoring system.

Conclusion: Bone results were more or less similar in both the groups. Functional results were a bit better in rail fixator group. Rate of complication were also similar in our study. However patients tolerated rail road with ease and application of rail fixator and comfortable distraction procedure had marginal benefit over Ilizarov.
\end{abstract}

Keywords: Ilizarov, Rail fixator, Non union, Long bones, Infection, Tibia.

\section{Introduction}

Fractures of long bones are on increase in incidence from last few decades due to increased road traffic accidents ${ }^{2}$ and other domestic accidents leading to increased incidence of severe open fractures of limbs. Complications also increases in open fractures which may lead to non union of these bones. Fracture of the shaft of long bone should not be considered a non union until atleast 6 months after the injury. ${ }^{1}$ Non union were more common when the fractures were ${ }^{1}:-$ open, infected, segmental, comminuted, insecurely fixed, immobilized for an insufficient time, treated by ill advised open reduction, distracted either by traction or by plate and screws, irradiated bones. Two types of non union has been described in literature. ${ }^{4}$ Hypervascular non union in which ends of the fragments are capable of biological reaction and avascular or atropic non union in which ends are inert and incapable of biological reaction.

Treatment of long bone non union is a very controversial subject to debate as various modes of treatments are available with varying results. Various devices used in treatment of non union are Iliarov fixator, intramedullary nail, dynamic compression plate, locking plate, limb reconstruction system / rail fixator etc.

Internal fixation with plates and intramedullary nail is not without the risk of infection. In case of established infection, bone loss these modalities do not serve the purpose. In these cases a treatment is required which will reconstruct as well as restore the full functional limb. Ilizarov ring fixator ${ }^{3}$ has achieved the purposed but its complications like persistent pain in joints and discomfort inspired the discovery of unilateral fixators. Rail road fixator is a type of unilateral fixator. Due to its simple application and comfort to the patient its more easily tolerated by the patients. Most modern unilateral fixators (rail road fixators/lrs) also have facility to distract or compress fractures and allow the dynamisation of the fractures which is a crucial need in such cases. ${ }^{4}$

Confusion still exists for exact union rates and complications related to Ilizarov \& rail road fixator/ LRS in treating non union. So this study was conducted to assess and compare the union rates in fracture non union of long bones and to assess complications as sociated with the Ilizarov and rail road fixator.

\section{Materials and Methods}

This study comprised of 30 patients from age group 21-60 years under two groups (15 cases each), conducted at Government Medical College, Rajindra Hospital, Patiala. Group A consisted of patients treated with Ilizarov fixator and group B of those treated with Rail road fixator. Informed consent of all the patients were taken. Mean age under group A was 37.6 years 
and that in group B was 40.5 years. $90 \%$ of the patients were males. Most of our application of Ilizarov (93.3\%) and Rail fixator $(86.6 \%)$ was on tibia. There was one case of femur in both groups and one humerus in group B. Middle one third was more commonly involved area in all the bones. 9 out of 15 patients in both groups had infected non union. On an average patient had 1.8 number of previous procedures on group A compared to 1.7 in group B. Average shortening present in group A was $2.9 \mathrm{~cm}$ with marginal difference in group B having $2.86 \mathrm{~cm}$ (Range 1-6 cm). 12 patients in group A gone through compression mode of treatment in group $\mathrm{A}$ and 13 in group B.

The technique for Ilizarov wire insertion includes passing the wire through skin and soft tissue, drilling it through near and far cortices of the bone. Use of lower drill speeds is recommended by some surgeons. The wires are attached to a series of half or full metal rings, which encircle the affected limb, and tensioned to enhance stability. The fixator is completed by connecting the rings with threaded rods aligned.

The rail road fixator was normally mounted laterally on femur and humerus, but in tibia it was mounted medially taking into consideration the safety of soft tissues and neurovascular structures. Careful stab skin incision and deep dissection was required in order to avoid damage to saphenous vein and nerve. The image intensifier was used to identify important bony landmarks and to define the axis of bone. This axis was parallel to final position of fixator.

We did an adequate debridement and resection of nonviable bone. Bone transport using above techniques in non-union of the fracture with bone gap of greater than $5 \mathrm{~cm}$ was done. In case of bone defects smaller than 5 centimeters, acute docking was done followed by distraction histiogenesis at the corticotomy site over an fixator. We did corticotomy at single site. Movements of Joint were started as early as possible after the operation. Transport was initiated after 5-7 days of the corticotomy. Rate of transport in our study was 1.00 $\mathrm{mm} /$ day in 4 divided parts. At the conclusion of transport, partial weight bearing was started.

The patient was discharged on the $2^{\text {nd }} / 3^{\text {rd }}$ postoperative day. We confirmed union on observing bridging callus on AP, lateral and oblique views; this was further confirmed clinically by dynamisation of the fixator and observing the ability of the patient to walk and perform a single-leg stance on the affected limb without apprehension or deformity at site. The fixator was removed when evident signs of union were present on X-ray. The limb was protected with POP cast for 4 weeks in most of the cases after the removal of the rail fixator/ Ilizarov.

\section{Results}

Infection was eradicated in $89 \%$ cases in either group. Shukla et al in 2013 had also shown eradication of infection in $91.6 \%$ of cases in their study. Average duration of Ilizarov application was 8.8 months and rail fixator duration was 8.3 months (range 6-15 months). Partial weight bearing was started at completion of distraction and full weight bearing started only after complete union. Skin grafting was done in 2 patients in group A and bone grafting was done in 1 case. In group $\mathrm{b}$ one patient had skin grafting. Four and six patients in respective group had pin tract infection and loosening in 1 and 2 patients in similar manner. We reinserted the loosened pins. In one case rail fixator was removed due to failure of treatment. We found range of motion was decreased where pins were close to the joint surface but revived in most cases. Union was achieved in $86.7 \%$ in group $\mathrm{A}$ and $93.3 \%$ in group $\mathrm{B}$. The result was excellent to good in $86.6 \%$ cases in both the groups. In Rail fixator group results were Fair in $1(6.66 \%)$ and poor in $1(6.66 \%)$ patient compared to 2 poor $(13.3 \%)$ in Ilizarov group as per ASAMI score [Table].

Table 1: Results according to ASAMI score

\begin{tabular}{|l|c|c|c|c|}
\hline & \multicolumn{2}{|c|}{ llizarov } & \multicolumn{2}{c|}{ Rail fixator } \\
\hline Results (Bone results) & No. of cases & Percentage & No. of cases & Percentage \\
\hline Excellent & 8 & $53.3 \%$ & 9 & $60 \%$ \\
\hline Good & 5 & $33.3 \%$ & 4 & $26.6 \%$ \\
\hline Fair & 0 & $0 \%$ & 1 & $6.6 \%$ \\
\hline Poor & 2 & $13.3 \%$ & 1 & $6.6 \%$ \\
\hline
\end{tabular}

\begin{tabular}{|c|c|c|c|}
\hline$\chi^{2}$ & Df & p-value & Significance \\
\hline 1.50 & 3 & 0.682 & NS \\
\hline
\end{tabular}

The results as per ASAMI classification (1995)

\begin{tabular}{|c|l|l|}
\hline Results & \multicolumn{1}{|c|}{ Bone results } & \multicolumn{1}{c|}{ Functional results } \\
\hline Excellent & Bone union & Ability to perform previous activities of daily living \\
& $\begin{array}{l}\text { No infection } \\
\text { Deformity }<7 \text { degree } \\
\text { Limb length discrepancy }<2.5 \mathrm{~cm}\end{array}$ & $\begin{array}{l}\text { (AD). No pain or mild pain, no limp, no soft tis sue } \\
\text { sympathetic dystrophy, knee or ankle joint contracture } \\
\end{array}$ \\
\hline
\end{tabular}




\begin{tabular}{|l|l|l|}
\hline Good & $\begin{array}{l}\text { Bone union } \\
\text { Failure to achieve one of the above } \\
\text { criteria }\end{array}$ & $\begin{array}{l}\text { Almost all ADL with minimal difficulty. Pain absent } \\
\text { or mild pain. Failure to meet one of the othercriteria }\end{array}$ \\
\hline Fair & $\begin{array}{l}\text { Bone union } \\
\text { Failure to achieve two of the other } \\
\text { criteria }\end{array}$ & $\begin{array}{l}\text { Most ADL but with minimal difficulty, no pain or mild } \\
\text { pain. Failure to meet two of the other criteria }\end{array}$ \\
\hline Poor & $\begin{array}{l}\text { Non union or re-fracture } \\
\text { Failure to meet three of the other } \\
\text { criteria }\end{array}$ & $\begin{array}{l}\text { Significantly limited ADL. Significant pain requiring } \\
\text { narcotics Failure to meet three of the other criteria }\end{array}$ \\
\hline
\end{tabular}

ADL=Activities of daily living, ASAMI=Associaion for the study and application of the method of Ilizarov

\section{Case No 1 (llizarov)}

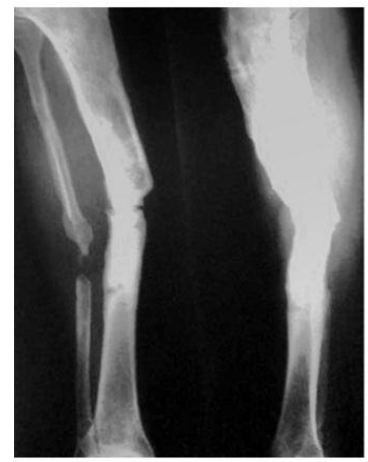

Fig. 1a: Pre-operative

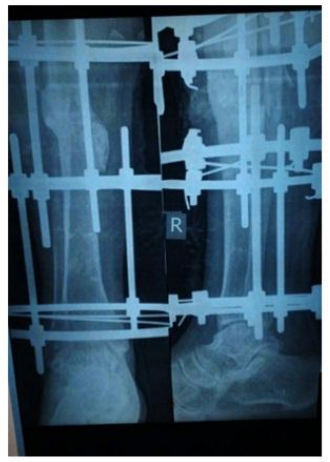

Fig. 1b: Showing union

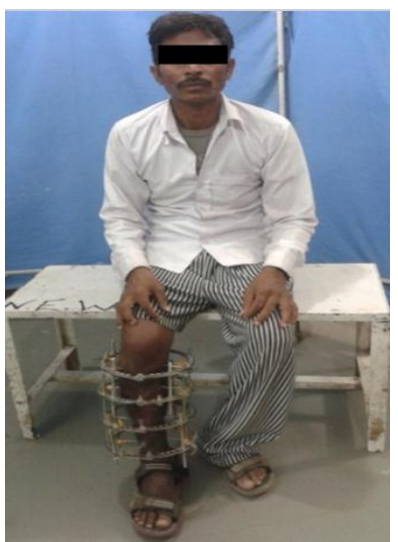

Fig. 2: Sitting with knee flexed

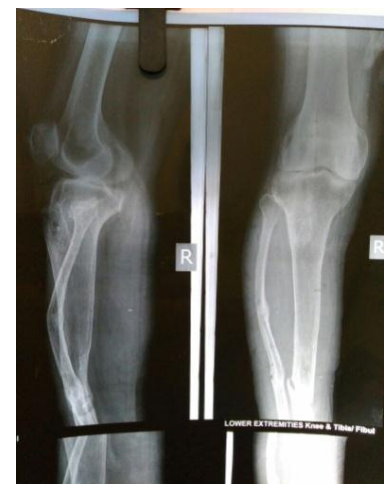

Fig. 3a: Pre- Operative

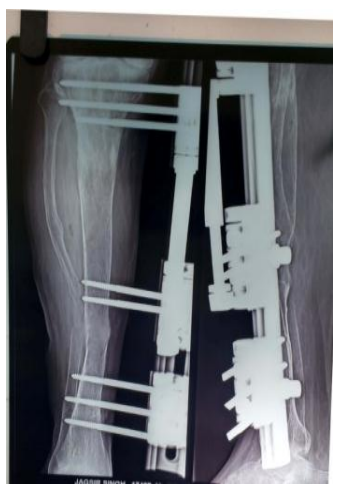

Fig. 3b: Showing Union

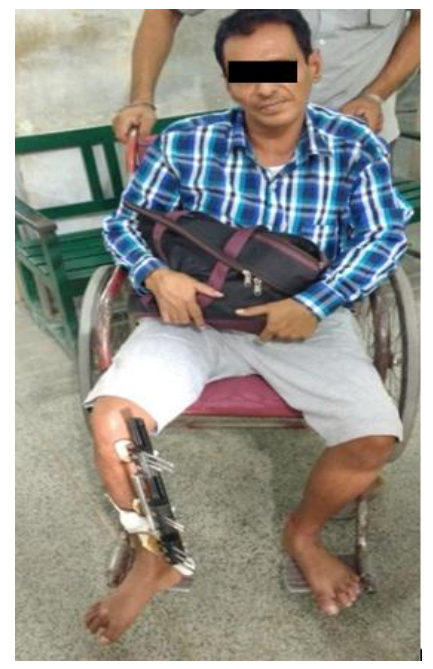

Fig. 4: Sitting with knees flexed

\section{Case No 2 (Rail Road)}

Table 3: Limb length discrepancy

\begin{tabular}{|c|c|c|c|c|}
\hline \multirow{2}{*}{$\begin{array}{c}\text { Limb length } \\
\text { discrepancy }\end{array}$} & \multicolumn{2}{|c|}{ Rail Fixator } & \multicolumn{2}{c|}{ llizarov } \\
\cline { 2 - 5 } & No. of patients & Percentage & No. of patients & Percentage \\
\hline Same as before & 11 & $73.3 \%$ & 10 & $46.7 \%$ \\
\hline $0-1 \mathrm{~cm}$ & 2 & $13.3 \%$ & 2 & $6.7 \%$ \\
\hline $1-3 \mathrm{cms}$ & 2 & $13.3 \%$ & 3 & $6.7 \%$ \\
\hline
\end{tabular}

\begin{tabular}{|c|c|c|c|}
\hline$\chi^{2}$ & Df & p-value & Significance \\
\hline 0.248 & 2 & 0.884 & NS \\
\hline
\end{tabular}




\section{Chart 1:}

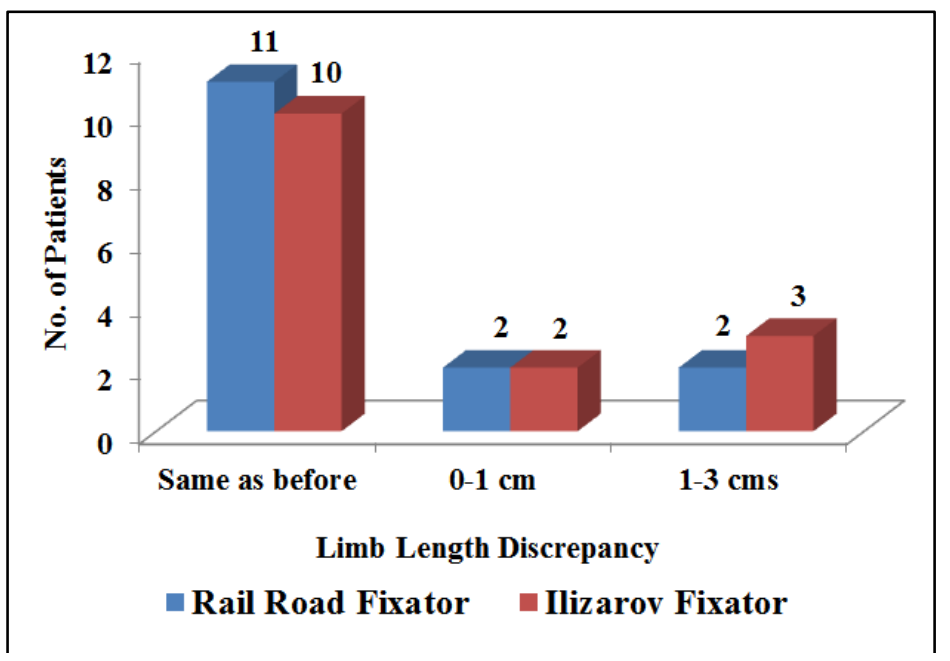

Table 4: Duration of treatment

\begin{tabular}{|l|c|c|c|c|}
\hline \multirow{2}{*}{$\begin{array}{c}\text { Duration } \\
\text { (months) }\end{array}$} & \multicolumn{2}{|c|}{ Rail Fixator } & \multicolumn{2}{c|}{ llizarov } \\
\cline { 2 - 5 } & No. of cases & Percentage & No. of cases & Percentage \\
\hline$<4$ months & 1 & $6.6 \%$ & 0 & $0 \%$ \\
\hline $4-6$ months & - & $0 \%$ & 1 & $6.6 \%$ \\
\hline $6-8$ months & 9 & $60 \%$ & 6 & $40 \%$ \\
\hline $8-10$ months & 3 & $20 \%$ & 5 & $33.3 \%$ \\
\hline$>10$ months & 2 & $13.33 \%$ & 3 & $20 \%$ \\
\hline
\end{tabular}

\begin{tabular}{|c|c|c|c|}
\hline$\chi^{\mathbf{2}}$ & Df & p-value & Significance \\
\hline 3.30 & 4 & 0.509 & NS \\
\hline
\end{tabular}

Chart 2:

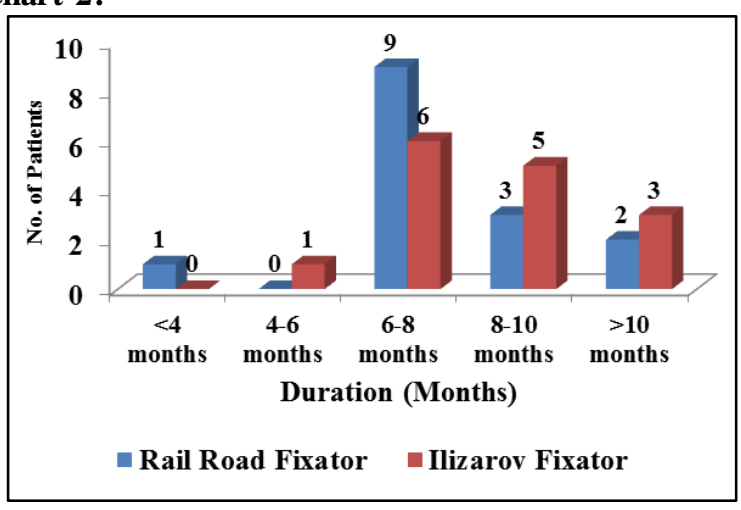

\section{Discussion}

Reconstruction for infected non-union is difficult; the associated bone defect, shortening, and deformity may further complicate matters. Ilizarov ${ }^{5}$ from more than 60 years back had studied the effect of stabilization in fracture and followed reconstruction of injured limb. Most of studies by him were based on the effects of principal of gradual stretching of a bilogical tissue by distraction and its effects on triggering of tis sue growth and regeneration. Based on his studies the basic technique developed by Ilizarov was distraction histiogenesis. ${ }^{6,7}$ It is mechanical induction of new bone formation bony surfaces that are gradually pulled apart.
The success of results gained by Ilizarov fixator ${ }^{8}$ bear an evidence to the success of this system. However, due to certain complications ${ }^{9}$ such as heavy apparatus, persistent pain, deformity of joints and discomfort caused by Ilizarov ring fixator inspired the development of monolateral frame devices. Rail Fixator ${ }^{10,11}$ is one such device. Our main objective was to study and compare the union rates and rate of complication in non union cases by use of these devices.

In our study 18 out of 30 patients were in age group of 21 to 40 years whereas 12 patients belonged to the age group of 41 to 60 years. Mean age under group A was 37.6 years and that in group B was 40.5 years. ${ }^{12}$ 27 patients were male out of 30 patients, while female were 3 in number. Near similar observations regarding age and sex, nature of trauma have been reported in study by shukla et $\mathrm{al}^{13}$ Jain et $\mathrm{al}^{14}$ \& wang et al. ${ }^{15}$ Most of our applications were on tibia ${ }^{15}$ in either group. In literature also most studies ${ }^{13,16-19}$ are on tibia. There was one case of femur in group A and one femur and one humerus in group B. Middle one third was most commonly involved in all the bones. 9 patients out of 15 patients had infected nonunion whereas 6 patients had non infected type of non union in both groups. Infection was eradicated in $8(89 \%)$ cases in either group. $^{13,20}$ 
Average number of previous surgeries was $1.8(0-$ 4 ) in Ilizarov group compared to $1.7(0-4)$ in Rail fixator group. ${ }^{20,21}$ Average shortening present in the limb was $2.9 \mathrm{~cm}$ in Ilizarov group ${ }^{14}$ compared to 2.86 $\mathrm{cm}$ in Rail fixator group. ${ }^{22} 12$ patients underwent acute docking or compression in ilizarov group compared to 13 in rail fixator group. 2 patients underwent compression - distraction for treatment of non union in Rail fixator group compared to 3 patients in Ilizarov group. Distraction was done at the rate of $1.00 \mathrm{~mm}$ per day in 4 equal installments of $0.25 \mathrm{~mm}$ each, every 6 hourly after $14^{\text {th }}$ day of corticotomy. Patients were followed up every 6 weeks, 12 weeks and 24 weeks to look for regenerate radiographically for the assessment of union. Joint movements were started as soon as possible after the operation. Partial weight bearing was started on completion of distraction and full weight bearing started after complete union in both groups.

Average duration of application was 8.8 months ${ }^{14}$ in patients of Ilizarov compared to 8.3 months in rail fixator ${ }^{18,23}$ group. Lengthening achieved in 2 patients of compression distraction was of the average $2.33 \mathrm{~cm}$ average gain in 3 patients in Ilizarov group compared to $2.5 \mathrm{~cm}$ in Rail fixator group. Only 1 patient required split skin grafting as secondary procedure in Rail fixator group compared to 2 patients in Ilizarov group. Further 1 patient in latter group required bone grafting. Most common problem was pin tract infection ${ }^{24}(6 \& 4$ patients), followed by loosening of pins ( $1 \& 2$ cases $)$ in respective groups and decreased range of motion of adjacent joints. In our study union ${ }^{13}$ was achieved in 14 patients out of 15 patients $(93.3 \%)$ in patients of non union of long bones by application of rail road fixator. In Ilizarov group union was achieved in 13 out of 15 $(86.7 \%)^{20}$ patients.

According to ASAMI criteria for bone results we had 8 excellent, 5 good, 0 fair and 2 poor results in

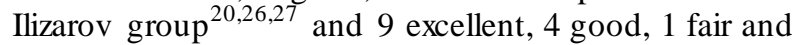
1 poor results in Rail fixator ${ }^{14,25}$ group. Functional results as per ASAMI criteria were 5 good, 1 fair and 2 poor in Ilizarov group compared to 6 good, 1 fair and 1 poor in rail fixator group including 7 excellent in both the groups. Our results compare well with the studies in the literature ${ }^{14,17,18,20,25}$

\section{Conclusion}

ASAMI score comparison tells that bone results and functional results are similar in both the treatment groups. It was observed that rail road fixator and Ilizarov are excellent tools to treat non union of long bones due to any cause (excluding congenital and pathological causes of non union as per exclusion criteria) accompanying with extensive soft tissue damage, shortening, and deformity. Also the complications arising in two modalities are also not much different from each other. Duration of treatment is slightly lesser with rail fixator in our study. Rail fixator had more patient compliance and ease of application. This apparatus is easy to apply with shorter learning curve and less cumbersome to the patient as compared to illizarov.

\section{Conflict of Interest: Nil}

\section{Source of Funding: Nil}

Consent: Consent taken from all the patients as per consent form in written.

Ethical Study: Study is done as per ethics committee of the institute.

\section{References}

1. Cleveland Kevin B, Delayed Union and Nonunion of Fractures. In Campbell's Operative Orthopaedics. Mosby Elsevier, Philadelphia, Pennsylvania, USA, 2008;11(3):3533.

2. Tolon-Becerra A, Lastra-Bravo X, Flores-Parra I National and regional analysis of road accidents in Spain. Traffic Inj Prev 2013;14:486-95.

3. Dinh P, Hutchinson BK, Zalavras C, Stevanovic MV. Reconstruction of osteomyelitis defects. Semin Plast Surg 2009;23:108-18.

4. Charles M, Court- Brown,Ed, "Fracture of The tibia and fibula" ; chapter 52, Rockwood and Green's fractures in adults: $6^{\text {th }}$ edition, vol:2, Section 4, Lippincott Williams and Wilkins, Philadelphia, USA, 2006, 2113pp.

5. Ilizarov GA. The tension-stress effect on the genesis and growth of tissues: Part I. The influence of stability of fixation and soft-tissue preservation. Clin Orthop Relat Res 1989;238:249-81.

6. Catagni MA, Guerreschi F, Holman JA, Cattaneo R. Distraction osteogenesis in the treatment of stiff hypertrophic nonunions using the Ilizarov apparatus. Clin Orthop Relat Res 1994;301:159-63.

7. Dendrinos GK, Kontos S, Lyritsis E. Use of the Ilizarov technique for treatment of non-union of the tibia associated with infection. J Bone Joint Surg Am. 1995 Jun;77(6):835-46.

8. Saleh M, Royston S. Management of nonunion of fractures by distraction with correction of angulation and shortening. J Bone Joint Surg Br 1996;78:105-9.

9. Ramos T, Karlsson J, Eriksson BI, Nistor L. Treatment of distal tibial fractures with the Ilizarov external fixat or $-\mathrm{A}$ prospective observational study in 39 consecutive patients. BMC Musculoskelet Disord 2013;14:30.

10. Noonan KJ, Leyes M, Forriol F, Cañadell J. Distraction osteogenesis of the lower extremity with use of monolateral external fixation. A study of two hundred and sixty - one femora and tibiae. J Bone Joint Surg Am 1998;80:793-806.

11. Sangkaew C. Distraction osteogenesis of the femur using conventional monolateral external fixat or. Arch Orthop Trauma Surg 2008;128:889-99.

12. Khan MS, Rashid H, Umer M, Qadir I, Hafeez K, Iqbal A. Salvage of infected non-union of the tibia with an Ilizarov ring fixator. J Orthop Surg (Hong Kong). 2015 Apr;23(1):52-5

13. Seenappa HK, Shukla MK, Narasimhaiah M. Management of complex long bone nonunions using limb reconstruction system. Indian J Orthop 2013;47:602-7.** J Orthop Surg (Hong Kong). 2015 Apr;23(1):52-5. 
14. Jain SR, Shah HM, Shetty N, Patel M, Tekkati RK, Khanna A. Study of efficacy of ilizarov external fixation in infected non union tibial fractures. Journal Medical Thesis 2014;2(1):16-18.

15. Wang XG, Wang W, Wang XY, Lü L, Wang GQ, Ma QS, et al. One stage treatment of infected tibial defects combined with skin defects with Ilizarov technique. Zhongguo Gu Shang 2010;23:422-5.

16. Zheng Q, Wu HB, Li H, Pan ZJ. Tibial infected nonunion treated by internal bone transport using the mono-lateral external fixation. Zhonghua Wai Ke Za Zhi. $2006 \mathrm{Apr}$ 15;44(8):544-6.

17. Lavini F, Dall'Oca C, Bartolozzi P. Bone transport and compression-distraction in the treatment of bone loss of the lower limbs. Injury. 2010 Nov;41(11):1191-5.

18. Singh B,Aggarwal RK, Chohan S,Singh N. Infected non union tibia treated with monorail fixat or and effect of early weight bearing on union and regenerate. Pb Journal of Orthopaedics2013; Vol-XIV, No.1.

19. Harshwal RK, Sankhala SS,Jalan D. Management of nonunion of lower-extremity long bones using monolateral external fixator - Report of 37 cases. Injury.2014Mar;45(3):560-7.

20. Khanfour AA and Mohamed M. El-Sayed. Efficacy of a compliant semicircular Ilizarov pin fixat or module for treating infected nonunion of the femoral diaphysis. Strategies Trauma Limb Reconstr. Aug 2014;9(2): 101109

21. Oztürkmen Y, Doğrul C, Karli M.Results of the Ilizarov method in the treatment of pseudoarthrosis of the lower extremities. Acta Orthop Traumatol Turc. 2003;37(1):918.

22. Kocaoglu, Mehmet, Eralp, Levent, Sen, Cengiz et al. Management of Stiff Hypertrophic Nonunions by Distraction Osteogenesis: A Report of 16 Cases. Lippincott Williams \& Wilkins, Inc. Volume 17(8), September 2003, pp 543-548.

23. Sen C, Eralp L, Gunes T, Erdem M, Ozden

VE, Kocaoglu M. An alternative method for the treatment of nonunion of the tibia with bone loss. J Bone Joint Surg Br. 2006 Jun;88(6):783-9.

24. Arora S, Batra S, Gupta V, Goyal A.Distraction osteogenesis using a monolateral external fixator for infected non-union of the femur with bone loss. J Orthop Surg (Hong Kong). 2012 Aug;20(2):185-90.

25. Lakhani A, Singh D, Singh R. Outcome of rail fixator system in reconstructing bone gap. Indian J Orthop. 2014 Nov-Dec; 48(6): 612-616.

26. Madhusudhan TR, Ramesh B, Manjunath K, Shah HM, Sundaresh DC, Krishnappa N. Outcomes of Ilizarov ring fixation in recalcitrant infected tibial non - unions-a prospective study. J Trauma Manag Outcomes 2008;2:6.

27. Chaddha M, Gulati D, Singh AP, Singh AP, Maini L. Management of massive posttraumatic bone defects in the lower limb with the Ilizarov technique. Acta Orthop Belg 2010;76:811-20. 